\title{
Ekstraksi Pektin dari Kulit Pisang Kepok (Musa paradisiaca) Menggunakan Pelarut HCl sebagai Edible Film
}

\author{
Megawati $^{1, \bowtie}$, Elfi Lutfiyatul Machsunah ${ }^{2}$
}

DOI 10.15294/jbat.v4i2.4177

${ }^{1}$ Jurusan Teknik Kimia, Fakultas Teknik, Universitas Negeri Semarang

${ }^{2}$ Semen Indonesia (persero) Tbk, Gresik, Surabaya

\section{Article Info}

Sejarah Artikel:

Diterima November 2015

Disetujui Mei 2016

Dipublikasikan Juni 2016

\section{Keywords :}

edible film, extraction, kepok peel, microwave assisted extraction, Musa paradisiaca, pectin

\begin{abstract}
Abstrak
Pisang merupakan jenis buah yang relatf banyak dikonsumsi oleh manusia, baik secara langsung ataupun diolah menjadi makanan lain. Sementara itu, kulit pisang biasanya hanya dibuang menjadi limbah, padahal di dalam kulit pisang terdapat pektin sebanyak $22,4 \%$. Oleh karen itu, ekstraksi pektin dari kulit pisang penting untuk dilakukan. Pada penelitian ini dilakukan ekstraksi pektin dari kulit pisang kepok (Musa paradisiaca) menggunakan pelarut $\mathrm{HCl}$ dan metode pemanasan Microwave Asisted Extraction (MAE) yang bertujuan untuk mengetahui yield pektin pada berat bahan 10 dan $15 \mathrm{~g}$, daya $600 \mathrm{~W}$, waktu 20 menit, dan konsentrasi $\mathrm{HCl} 0,25 \%$ sebanyak $300 \mathrm{~mL}$. Ekstraksi menggunakan cara pemanasan secara konvensional juga dikerjakan supaya hasil dari metode MAE dapat dibandingkan. Hasil penelitian menunjukkan bahwa metode MAE menghasilkan pektin 8,9 dan 16,53\% w/w kering, masing-masing untuk berat bahan 10 dan $15 \mathrm{~g}$. Hal ini menunjukkan pada berat bahan $15 \mathrm{~g}$, yield pektin menggunakan MAE lebih besar daripada pemanasan konvensional $(12,8 \%)$.Hasil uji FTIR menandakan adanya pektin, yang terdiri atas gugus karbonil pada 1623,17 dan $1632,81 \mathrm{~cm}^{-1}$, gugus C-O pada 1230,64 dan 1231,60 $\mathrm{cm}^{-1}$, dan gugus C-C siklik pada 1143,84 dan $1146,73 \mathrm{~cm}^{-1}$. Pektin kulit pisang kepok yang didapatkan dapat digunakan sebagai bahan pembuatan edible film dengan menambahkan plasticizer.
\end{abstract}

\begin{abstract}
Banana fruit consumption in several areas of Indonesia is relatively high. Meanwhile, banana peel as its waste is not utilized well. Whereas, the banana peel contains pectin about $22.4 \%$. Therefore, it is important to study the extraction of pectin from banana peel using $\mathrm{HCl}$ as solvent and Asisted Microwave Extraction (MAE) as heating method. The used banana type is kepok (Musa paradisiaca). The extraction was conducted at condition as follows; banana peel weights of 10 and $15 \mathrm{~g}$, electrical power of $600 \mathrm{~W}$, duration of $20 \mathrm{~min}$, and hydrochloric acid concentration of $0.25 \%$ with volume of 300 $m L$. The extraction using conventional heating method was also performed to evaluate the pectin yield of the MAE result. The experimental results showed that the MAE method produce pectin of 8.9 and $16.53 \% \mathrm{w} / \mathrm{w}$ dry for banana peel weight of 10 and $15 \mathrm{~g}$, respectively. This shows that the MAE using raw material weight of $15 \mathrm{~g}$ produced pectin (16.53\%) greater than conventional heating (12.8\%). FTIR test results indicate that the produced chemical compound is pectin, which consists of a carbonyl group at 1623.17 and $1632.81 \mathrm{~cm}^{-1}$, the CO group at 1230.64 and $1231.60 \mathrm{~cm}^{-1}$, and CC cyclic group 1143.84 and $1146.73 \mathrm{~cm}^{-1}$ for banana peel weight of 10 and $15 \mathrm{~g}$, respectively. The obtained pectin can be used as raw material for edible film production by adding plasticizers.
\end{abstract}




\section{PENDAHULUAN}

Bahan pangan berbentuk segar maupun hasil olahannya mudah rusak apabila cara penyimpanannya tidak ditangani dengan baik. Kerusakannya dipercepat dengan terjadinya oksidasi terhadap makanan yang akan memperpendek umur simpan dan mengurangi nutrisi dari makanan itu sendiri. Dengan demikian pengemasan memiliki peran sangat penting (Anugrahati 2001 dalam Herdigenarosa 2013). Kemasan selain melindungi makanan, juga harus mempunyai sifat ramah lingkungan. Penggunaan polimer sintetik seperti plastik mempunyai peranan penting untuk pembungkusan produk makanan. Penggunaan plastik untuk kemasan makanan sudah meluas, tetapi tidak disertai perhatian terhadap dampak negatif yang ditimbulkannya (Megawati dan Ulinuha, 2014). Selain merusak lingkungan, penggunaan plastik juga berpotensi mengganggu kesehatan manusia, karena transfer senyawa dari kemasan plastik selama penyimpanan dapat menimbulkan resiko keracunan (Budiyanto 2008 dalam Herdigenarosa 2013).

Salah satu alternatif bahan pelindung untuk kemasan bahan pangan yang ramah lingkungan (biodegradable) yang bisa dipilih adalah edible film (Wahyono 2009 dalam Nugroho dkk. 2013). Edible film berupa lapisan tipis yang dapat digunakan melapisi makanan atau dicampur komponen - komponen lain makanan untuk menahan transfer massa air, oksigen, lemak, dan cahaya atau berfungsi sebagai pembawa bahan tambahan pangan (Krochta 1997 dalam Nugroho dkk. 2013). Keuntungan edible film antara lain dapat dikonsumsi langsung bersama produk yang dikemas, tidak mencemari lingkungan, memperbaiki sifat organoleptik produk yang dikemas, serta berfungsi sebagai suplemen penambah nutrisi, sebagai flavor, pewarna, zat antimikroba, dan antioksidan (Murdianto 2005 dalam Nugroho dkk. 2013).

Salah satu bahan dasar pembuatan edible film adalah pektin (Megawati dan Ulinuha, 2014). Pektin merupakan senyawa polisakarida kompleks dengan komponen utama asam D-galakturonat (Rouse 1977 dalam Fitriani 2003). Kenyataannya, pektin memiliki sifat gel yang baik sehingga dapat digunakan untuk membuat kemasan yang dapat dimakan. Pektin dapat diperoleh dari kulit buahbuahan seperti kulit pisang, kakao, markisa, jeruk bali, buah naga, dan lain-lain. Kulit pisang adalah limbah hasil industri pengolahan pisang untuk berbagai jenis makanan yang tidak bernilai ekonomi dan ramah lingkungan, sehingga penting untuk dicarikan solusi pemanfaatannya). Selain itu, pisang adalah buah-buahan tropis yang paling banyak dihasilkan dan dimanfaatkan oleh masyarakat Indonesia (Nainggolan, 1999). Produksinya menduduki peringkat pertama hasil pertanian di Indonesia. Bobot kulit pisang mencapai $40 \%$ dari buahnya. Dengan demikian kulit pisang menghasilkan limbah dengan volume yang besar. Salah satunya adalah jenis pisang kepok (Tarigan dkk., 2012). Oleh karenanya, kulit pisang merupakan alternatif yang menjanjikan untuk diambil pektinnya dan diolah menjadi edible film.

Pengambilan pektin dalam kulit pisang dapat dilakukan menggunakan beberapa cara ekstraksi, yang sering dibedakan menggunakan cara konvensional dan modern. Selama ini, ekstraksi pektin dilakukan menggunakan pelarut dengan pemanasan langsung. Sedangkan, caracara esktraksi pektin modern di antaranya ekstraksi dibantu oleh gelombang mikro dan ultrasonik sebagai sumber pemanasnya. Istilah ekstraksi yang sumber energinya dibantu oleh radiasi gelombang mikro ini sering disebut dengan Microwave Assisted Extraction (MAE). Ekstraksi pektin kulit pisang secara konvensional sudah pernah dilakukan pada variasi suhu, variasi $\mathrm{pH}$, volum pelarut, waktu ekstraksi, dan jenis pelarut (Woo dkk. 2010; Tang dkk. 2011; Nazaruddin dkk. 2011; Ismail dkk. 2012; Sulihono dkk. 2012). Menurut Nazaruddin dkk (2011) pelarut asam klorida menghasilkan yield paling tinggi. Secara keseluruhan disimpulkan bahwa ekstraksi secara konvensional dengan panas yang berlebihan dapat menyebabkan kerusakan pektin sehingga menurunkan kualitasnya. Selain itu, panjangnya waktu yang diperlukan untuk ekstraksi konvensional menyebabkan energi yang diperlukan untuk pemanasan juga semakin tinggi (Purwanto, 2010; Fishman 2000 dalam Sudiyono 2012). Penelitian ini memilih cara ekstraksi pektin kulit pisang menggunakan gelombang mikro sebagai sumber pemanas.Pektin hasil ekstraksi dapat diolah menjadi edible film.

Edible film dari pektin masih memiliki kekurangan sehingga dibutuhkan zat aditif untuk memperbaiki sifatnya, seperti plasticizer karena dapat meningkatkan elastisitas pada suatu material 
(Darni dkk. 2009 dalam Herdigenarosa 2013). Sorbitol dan gliserol merupakan jenis plasticizer yang dapat digunakan dalam pembuatan edible film. Pembuatan edible film dari pektin yang berasal dari sumber-sumber yang berbeda dengan plasticizer gliserol dan sorbitol telah dilakukan, namun pembuatan ediblefilm yang berasal dari pektin kulit pisang belum banyak dilakukan dan dikembangkan di Indonesia. Sehingga diharapkan menjadi bahan informasi sebagai kemasan pangan alternatif yang aman dan ramah lingkungan (biodegradable) serta mengurangi penggunaan kemasan plastik sintetik (non biodegradable) yang masih dominan hingga melihat pengaruh gliserol terhadap karakteristik edible film yang dihasilkan. Pektin hasil ekstraksi kulit pisang kepok memiliki karakteristik yang khas, sehingga perlu diuji kemungkinannya sebagai bahan baku edible film (Ismail dkk. 2012).

Berdasarkan permasalahan tersebut di atas, maka ekstraksi pektin kulit pisangkepok dengan pelarut asam klorida menggunakan metode MAE perlu dilakukan. Untuk mengetahui berat bahan supaya prosesnya ekonomis dan efisien, pektin yang digunakan sebesar 10 dan 15 g. Pektin hasil ekstraksi suatu bahan memiliki keunikan komposisinya, sehingga perlu dipelajari bagaimana cara membuat edible film berbasis pektin tersebut. Jenis plasticizer yang akan digunakan adalah sorbitol, karena merupakan jenis platicizer yang sering digunakan. Selanjutnya, kualitas edible film pektin kulit pisang kepok dari proses ini akan dievaluasi kelayakannya untuk melindungi buah jeruk yang sudah dikupas.

\section{METODE PENELITIAN}

Bahan yang digunakan dalam penelitian ini antara lain: kulit pisang kepok (Musa paradisiaca), $\mathrm{NaOH}, \mathrm{HCl}$, asam oksalat, aquades, etanol 96\%, dan indikator $\mathrm{pH}$. Ada beberapa tahapan yang dilakukan, meliputi preparasi bahan baku, ekstraksi menggunakan metode konvensional dan MAE, dan pembuatan edible film. Ekstraksi menggunakan metode konvensional digunakan sebagai acuan untuk mengevaluasi efektivitas metode MAE dari perbandingan yield pektin yang diperoleh. Ekstraksi menggunakan MAE dengan variasi berat bahan dilakukan untuk mengetahui pengaruhnya terhadap yield pektin. Kelayakan edible film hasil pencampuran pektin hasil ekstraksi dengan plasticizer dipelajari untuk melapisi potongan jeruk keprok. Pada proses preparasi, bahan baku kulit pisang kepok segar dijemur di bawah sinar matahari, kemudian dipotong kecil-kecil menggunkan pisau, dan dikeringkan kembali. Setelah kering, kulit pisang dihaluskan menggunakan blender dan diayak menggunakan saringan kawat (100 mesh).

Ekstraksi pektin menggunakan metode konvensional diproses pada kondisi serbuk kulit pisang $5 \mathrm{~g}$, aquades $40 \mathrm{~mL}$, dan waktu 80 menit. Proses ini menggunakan pemanasan langsung dari hot plate stirrer untuk mencapai kebutuhan pemanasan dan pengadukan. Kemudian larutan ditambahkan aquades $50 \mathrm{~mL}$, disusul dengan penyaringan. Pektin yang diperoleh dicuci supaya terbebas dari pelarutnya menggunakan aquades 25 $\mathrm{mL}$, indikator $\mathrm{pp}$ (phenolftalein)2 tetes, dan dititrasi dengan $\mathrm{NaOH} 1 \mathrm{~N}$ sampai titik jenuhnya tercapai. Setelah itu, ditambahkan $\mathrm{NaOH} 1 \mathrm{~N}$ sebanyak 1 $\mathrm{mL}$ dan dibiarkan selama 1 malam. Untuk memastikan pektin terbebas dari $\mathrm{NaOH}$, maka ditambahkan asam asetat $1 \mathrm{~N}$ sebanyak $5 \mathrm{~mL}$ hingga warna menjadi jernih. Setelah dibiarkan selama 5 menit tambahkan kalsium klorida $1 \mathrm{~N}$ 2,5 $\mathrm{mL}$ dan diaduk sampai rata. Endapan pektin disaring dan dikeringkan pada suhu $102{ }^{\circ} \mathrm{C}$, kemudian ditimbang setelah disimpan beberapa menit di desikator. Pencucian endapan pectin dilakukan kembali menggunakan dengan air panas untuk menghilangkan klorida. Tahap ini sangat penting guna memastikan pektin yang akan digunakan sebagai edible film tidak mengandung senyawa asam, sehingga aman untuk dikonsumsi. Tahapannya dilakukan dengan memanaskan pectin dalam oven sampai berat konstan.

Ekstraksi pektin menggunakan metode MAE dengan berat bahan baku berbeda (10 dan 15 g), daya $600 \mathrm{~W}$, asam klorida $0,25 \%$ sebanyak 300 $\mathrm{mL}$, dan waktu 20 menit. 5. Supaya gel pektin menggumpal dan kemudian memisah ditambahkan etanol 96\% (1:1,5). Proses dehidrasi ini dilakukan selama 12 jam supaya gumpalan pektin mengendap dengan sempurna. Setelah dipisahkan dari larutan menggunakan vacuum filter, pektin dikeringkan menggunakan oven pada suhu $65{ }^{\circ}$ Csampai berat konstan.Pektin hasil ekstraksi ini diuji menggunakanFourier Transform Infrared Spectroscopy (FTIR) untuk mengetahui komposisi dari pektin yang dihasilkan dan memastikan sebagai senyawa pektin.

Pektin yang dihasilkan dari ekstraksi menggunakan MAE digunakan sebagai bahan 

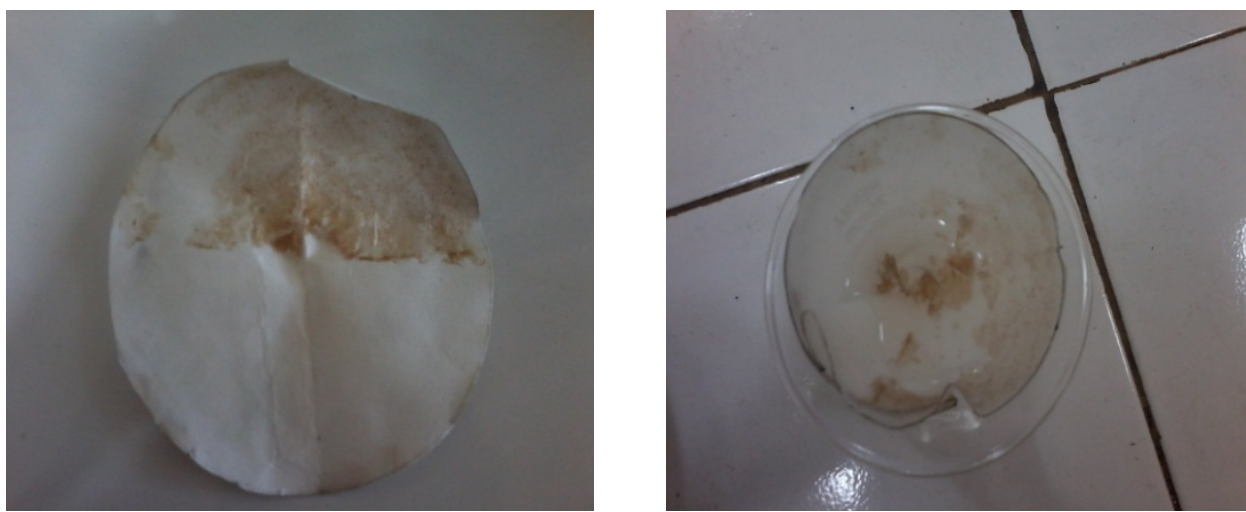

Gambar 1. Pektin Hasil Ekstraksi Menggunakan Metode Konvensional

pembuatan edible film dengan penambahan plasticizer. Pembuatan edible film dilakukan dengan melarutkan pectin $1,5 \mathrm{~g}$ ke dalam larutan $100 \mathrm{~mL}$ yang mengandung $0,6 \mathrm{~g}$ plasticizer/g pektin dengan disertai pengadukan selama 1,5 jam. Setelah itu dilakukan pemanasan pada suhu $70^{\circ} \mathrm{C}$ dan ditambahkan larutan $\mathrm{CaCl}_{2} \cdot 2 \mathrm{H}_{2} \mathrm{O}$ sebanyak 0,6 g dalam aquades $15 \mathrm{~mL}$ sedikit demi sedikit selama 30 menit. Larutan kemudian dituang dalam teflon dan dipanaskan dalam oven pada suhu $70^{\circ} \mathrm{C}$ selama 15 jam. Film yang sudah kering kemudian disimpan dalam desikator.

\section{HASIL DAN PEMBAHASAN}

Mengacu pada tujuan yang akan dicapai, beberapa hal yang akan dipelajari meliputi, preparasi bahan baku, analisis yield pektin standar, ekstraksi pektin menggunakan metode MAE (dengan berat bahan 10 dan $15 \mathrm{~g}$ ), serta aplikasinya sebagai edible film untuk melapisi makanan. Sebelum bahan digunakan untuk percobaan, perlu dilakukan preparasi terlebih dahulu dengan tujuan untuk mendapatkan serbuk kulit pisang kepok kering yang seragam serta memperluas area kontak antara partikel padatan dengan pelarut. Hal ini akan mengakibatkan ekstraksi berjalan lebih cepat. Selanjutnya dilakukan analisis yield pektin standar menggunakan ekstraksi konvensional. Hasil ekstraksi konvensional ini untuk mengetahui yield pektin standar dalam kulit pisang kepok yang digunakan. Kadar pektin dalam suatu bahan adalah bernilai spesifik, sehingga perlu dianalisis. Dilaporkan bahwa kondisi iklim, cuaca maupun geografis dapat mempengaruhi yield pektin yang dihasilkan. Yield pektin dari analisis standar pada kulit pisang kepok berdasarkan percobaan ini adalah 12,8\% w/w kering, serta bentuk dari pektinnya disajikan pada Gambar 1 .
Ekstraksi pektin kulit pisang kepok dalam percobaan ini dilakukan dengan menggunakan metode MAE, metode ini dipilih karena cocok bagi pengambilan senyawa yang bersifat termolabil seperti pektin. Metode MAE memiliki kontrol terhadap suhu yang lebih baik dibandingkan pemanasan konvensional, selain itu dengan MAE waktu ekstraksi lebih singkat, konsumsi energi dan solven lebih sedikit, yield lebih tinggi, serta akurasi dan presisi lebih tinggi (Purwanto, 2010). Sementara itu, jenis pelarut yang dipilih adalah larutan asam. Penggunaan asam dalam ekstraksi pektin adalah untuk menghidrolisis protopektin menjadi pektin yang larut dalam air ataupun membebaskan pektin dari ikatan dengan senyawa lain, misalnya selulosa (Fitriani, 2003).

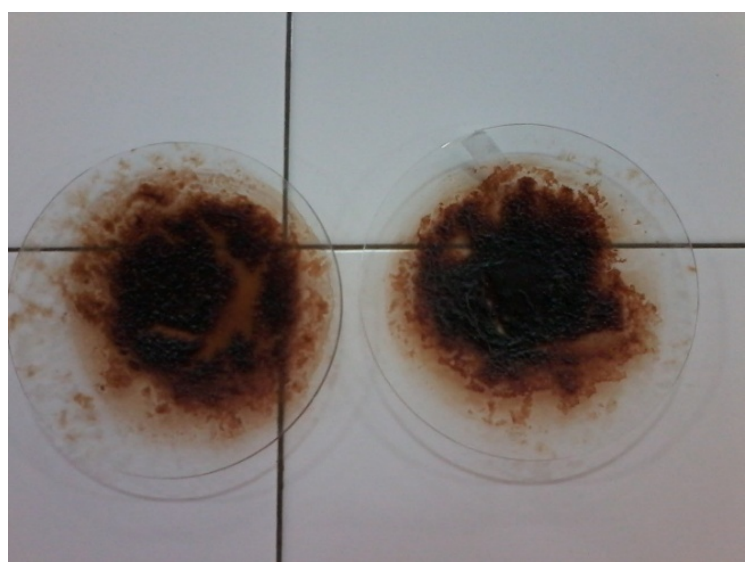

Gambar 2. Pektin Hasil Ekstraksi Menggunakan Metode MAE

Setelah proses ekstraksi selesai, kemudian dilakukan penggumpalan pektin. Penggumpalan ini diperlukan karena pektin terlarut memiliki gangguan terhadap kestabilan dispersi koloidalnya. Hal ini disebabkan pektin termasuk koloidal hidrofilik yang bermuatan negatif (dari gugus 


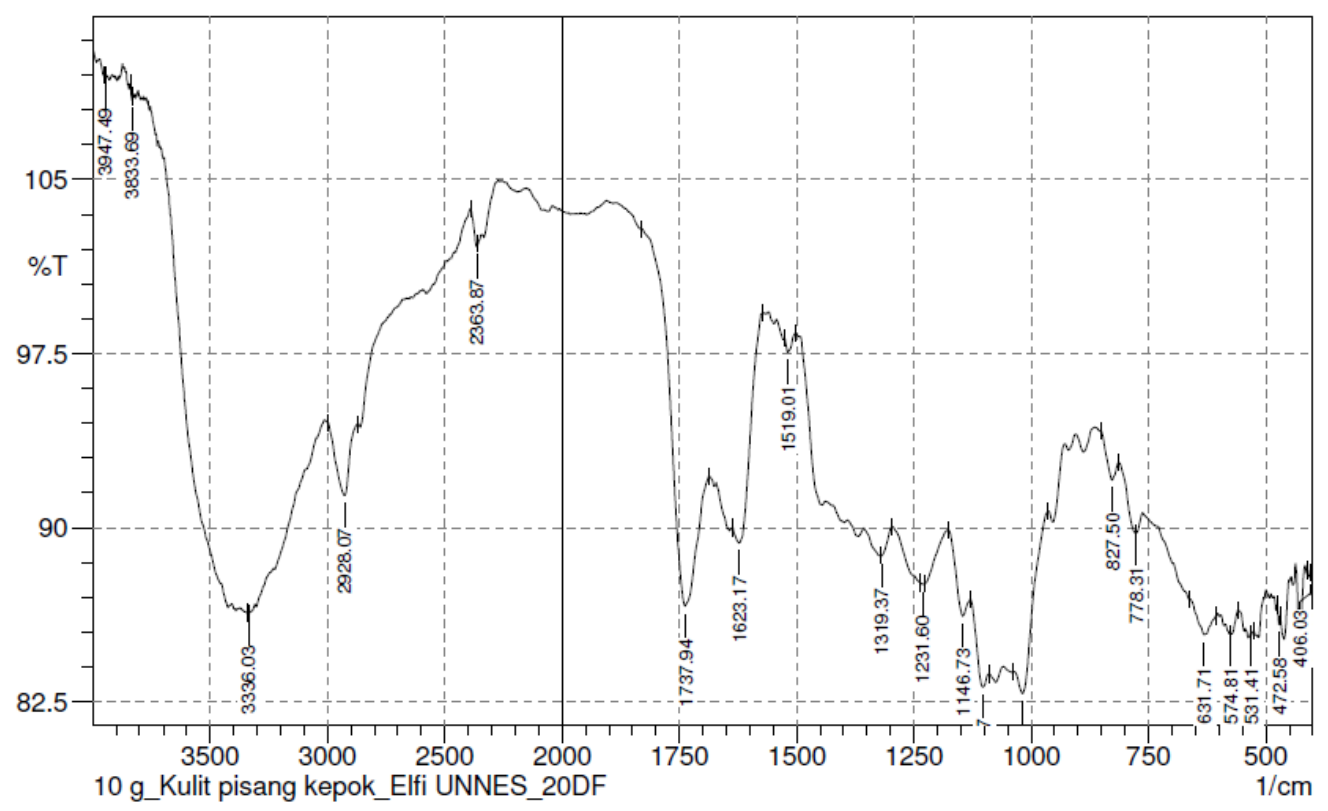

Gambar 3. Spektrum Pektin Kulit Pisang Kepok Hasil Ekstraksi Menggunakan Metode MAE (berat bahan $10 \mathrm{~g}$ )

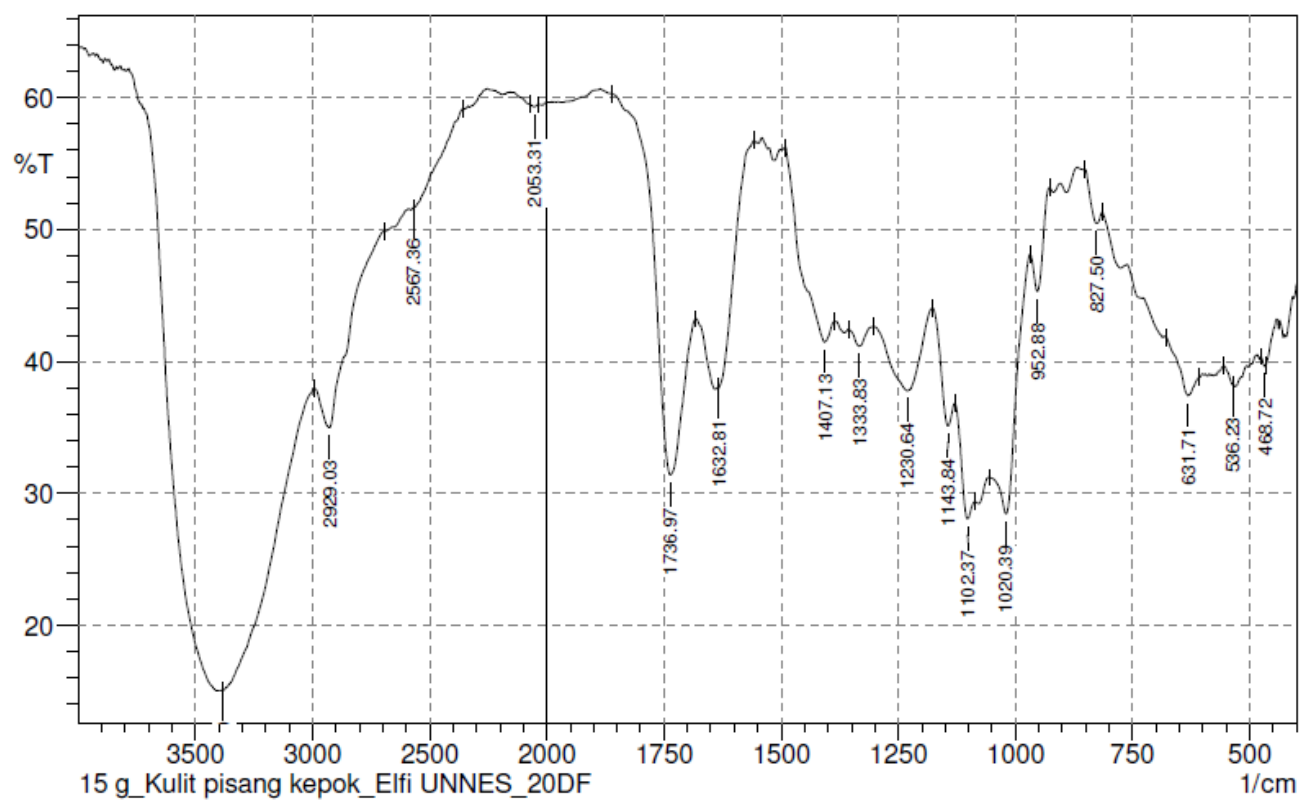

Gambar 4. Spektrum Pektin Kulit Pisang Kepok Hasil Ekstraksi Menggunakan Metode MAE (berat bahan $15 \mathrm{~g}$ )

karboksil bebas yang terionisasi) dan tidak mempunyai titik isolistrik. Seperti koloid hidrofilik umumnya, pektin distabilkan terutama oleh hidrasi partikelnya dariada oleh muatannya. Pektin distabilkan oleh selapis air melalui ikatan elektrostatik antara muatan negatif molekul pektin dan muatan positif molekul air. Penambahan zat pendehidrasi seperti alkohol dapat mengurangi stabilitas dispersi pektin karena efek dehidrasi mengganggu keseimbangan pektin-air, sehingga pektin akan menggumpal (Rouse 1977 dalam Fitriani 2003). Hasil penggumpalan pektin berwarna kecoklatan (Gambar 2). Terlihat bahwa pektin yang dihasilkan tidak jernih (kecoklatan).

Gel pektin yang didapatkan kemudian dilakukan pengeringan pada tekanan yang rendah, dengan tujuan agar pektin tidak terdegradasi ketika akan digunakan (Ranganna 1977 dalam Hariyati 2006). Jika pektin tidak dilakukan pengeringan, maka kondisi lembab pada gel pektin akan 
Tabel 1. Komposisi Senyawa Pektin Hasil Ekstraksi Kulit Pisang Kepok Menggunakan Metode MAE (Panjang gelombang $600 \mathrm{~W}$, waktu 20 menit, berat bahan $10 \mathrm{~g}$, dan pelarut asam klorida $0,25 \%$ sebanyak $300 \mathrm{~mL}$ )

\begin{tabular}{cll}
\hline Ikatan absorpsi $\left.\mathbf{( c m}^{-1}\right)$ & Gugus & Senyawa \\
\hline $3336,03-3500$ & $\mathrm{~N}-\mathrm{H}$ & Amina \\
1737,94 & $\mathrm{O}$ & Karboksilat \\
1623,17 & $\mathrm{RCOH}$ & Karbonil \\
1231,60 & $\mathrm{C}=\mathrm{O}$ & Alkohol, ester \\
1146,73 & $\mathrm{C}-\mathrm{O}$ & Eter \\
\hline
\end{tabular}

Tabel 2. Komposisi Senyawa Pektin Hasil Ekstraksi Kulit Pisang Kepok Menggunakan Metode MAE (Panjang gelombang $600 \mathrm{~W}$, waktu 20 menit, berat bahan $15 \mathrm{~g}$, dan pelarut asam klorida $0,25 \%$ sebanyak $300 \mathrm{~mL}$ )

\begin{tabular}{ccl}
\hline Ikatan absorpsi $\left(\mathbf{c m}^{-1}\right)$ & Gugus & Senyawa \\
\hline $3336,03-3500$ & $\mathrm{~N}-\mathrm{H}$ & Amina \\
1736,97 & $\mathrm{O}$ & Karboksilat \\
1632,81 & $\mathrm{RCOH}$ & Karbonil \\
1230,64 & $\mathrm{C}=\mathrm{O}$ & Alkohol, ester \\
1143,84 & $\mathrm{C}-\mathrm{O}$ & Eter \\
\hline
\end{tabular}

Tabel 3. Komposisi Senyawa Pektin (Ismail, 2012)

\begin{tabular}{ccl}
\hline Ikatan absorpsi $\left(\mathbf{c m}^{-1}\right)$ & Gugus & \multicolumn{1}{c}{ Senyawa } \\
\hline $1630-1650$ & $\mathrm{C}=\mathrm{O}$ & Karbonil \\
$1740-1760$ & $\mathrm{O}$ & Karboksilat \\
1100 & $\mathrm{RCOH}$ & Eter \\
1200 & $\mathrm{R}-\mathrm{O}-\mathrm{R}$ & Karbon siklik \\
\hline
\end{tabular}

dimanfaatkan oleh jamur untuk tumbuh dan berkembang biak, sehingga merusak pektin. Pektin yang sudah dikeringkan kemudian ditumbuk sampai pektin berbentuk serbuk halus, agar nantinya pektin mudah dilarutkan dalam pembuatan edible film.

Yield pektin menggunakan berat bahan 15 g lebih besar daripada $10 \mathrm{~g}$, masing-masing sebesar 8,9 dan $16,53 \% \mathrm{w} / \mathrm{w}$ kering. Hal ini menandakan bahwa berat bahan masih dapat ditingkatkan guna memdapatkan efisiensi proses yang optimal, karena kenaikan yieldnya sangat besar. Nilai yield ini juga mengindikasikan bahwa metode MAE menghasilkan yield lebih banyak daripada konvensional. Pektin yang didapatkan dari hasil ekstraksi selanjutnya dilakukan uji FTIR untuk mengidentifikasi kelompok bahan kimia utama dalam pektin, kelompok-kelompok fungsional utama pektin biasanya berada di wilayah antara 1.000 dan $2.000 \mathrm{~cm}^{-1}$ dari spektrum FTIR
(Kalapathy \& Proctor 2001 dalam Ismail 2012). Hasil uji FTIR untuk berat bahan 10 dan $15 \mathrm{~g}$ dapat dilihat pada Gambar 3 dan 4. Tabel 1 dan 2 menunjukkan komposisi senyawa pektin hasil percobaan dan Tabel 3 menunjukkan komposisi senyawa pektin dari pustaka.

Adanya gugus karbonil pada 1623,17 dan $1632,81 \mathrm{~cm}^{-1}$ menunjukkan bahwa sampel tersebut tergolong sebagai pektin, dan juga adanya gugus C-O pada 1230,64 dan 1231,60 $\mathrm{cm}^{-1}$. Gugus karbonil pada 1632,81 dan 1623,17 $\mathrm{cm}^{-1}$ menunjukkan bahwa sampel mengandung gugus ester. Ikatan absorpsi pada 1143,84 dan 1146,73 $\mathrm{cm}^{-1}$ berasal dari eter dan C-C siklik dalam struktur cincin molekul pektin (Ismail, 2012). Sekilas kedua grafik di atas nampak berbeda, pada berat bahan $10 \mathrm{~g}$ senyawa pektin nampak pada transmitan 82,5 sampai $105 \% \mathrm{~T}$, sedangkan pada berat bahan $15 \mathrm{~g}$ pada 20 sampai $60 \% \mathrm{~T}$. Perbedaan ini ternyata tidak terlalu signifikan, karena nila-nilai kisaran 


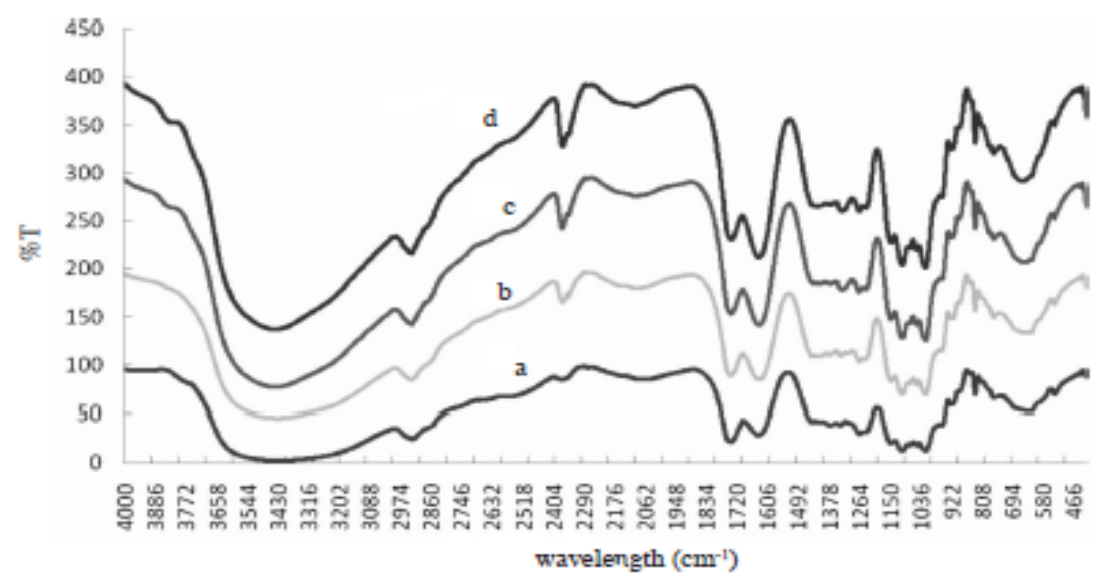

Gambar 5. Spektrum Pektin pada Berbagai Nilai Transmitan (sumber : Ismail, 2012)

transmitan di atas masih berada dalam daerah senyawa pektin. Hal ini dapat dijelaskan sebagai berikut. Menurut kurva FTIR pektin oleh Ismail (2012), lihat Gambar 5, masing-masing kurva memperlihatkan spektruk senyawa pektin pada nilai transmitan yang berbeda-beda.

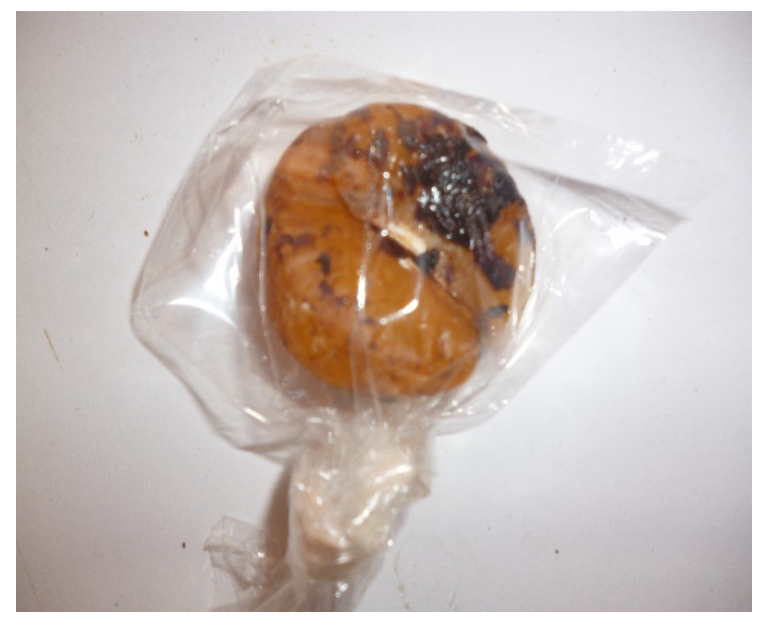

Gambar 6. Aplikasi Edible Film dari Pektin Kulit Pisang Kepok.

Pektin hasil ekstraksi kulit pisang kepok ini dapat diaplikasikan sebagai edible film untuk melapisi makanan. Hal ini merupakan salah satu contoh pemanfaatan pektin. Contoh pemanfaatan ini sudah dicoba untuk melapisi potongan buah jeruk keprok supaya awet dan kebersihannya tetap terjaga. Untuk dapat melapisi potongan buah jeruk, pektin yang sudah memadat dicairkan terlebih dahulu dengan cara pemanasan pelanpelan. Kondisi yang panas dan sangat encer kurang dapat melapisi potongan jeruk. Sehingga perlu didinginkan terlebih dahulu sebelum dioleskan pada jeruk dan secepatnya disimpan dalam lemari dingin. Hasil aplikasi tersebut disajikan pada Gambar 6. Halnya menunjukkan bahwa edible film yang dihasilkan masih memerlukan perlakuan lanjut untuk memiliki kualitas edible film yang dapat digunakan sebagai pelindung makanan.

\section{SIMPULAN}

Beberapa hal yang dapat disimpulkan dari hasil studi ini adalah yield pektin hasil ekstraksi kulit pisang kepok dengan pelarut asam klorida menggunakan metode konvensional sebesar 12,8\% $\mathrm{w} / \mathrm{w}$ kering. Sedangkan menggunakan metode MAE pada berat bahan $15 \mathrm{~g}$ menghasilkan yield yang lebih besar (16,53\% w/w kering). Sementara itu, pada berat bahan hanya $10 \mathrm{~g}$, menghasilkan yield pektin $8,9 \% \mathrm{w} / \mathrm{w}$. Untuk mendapatkan variabel proses yang lebih efisien dan ekonomis, berat bahan yang dicobakan perlu ditambah. Pektin yang diperoleh memiliki gugus karbonil pada 1623,17 dan $1632,81 \mathrm{~cm}^{-1}$, gugus C-O pada 1230,64 dan 1231,60 $\mathrm{cm}^{-1}$, dan gugus C-C siklik pada 1143,84 dan $1146,73 \mathrm{~cm}^{-1}$. Pektin kulit pisang kepok dapat digunakan sebagai bahan edible film dengan menambahkan plasticizer. Jenis plasticizer yang dipakai perlu untuk dipelajari lebih lanjut.

\section{DAFTAR PUSTAKA}

Fitriani, V. 2003. Ekstraksi dan Karakterisasi Pektin dari Kulit Jeruk Lemon (Citrus medica var Lemon). Skripsi. Institut Pertanian Bogor. Bogor. 
Hariyati, M.N. 2006. Ekstraksi dan Karakterisasi Pektin dari Limbah Proses Pengolahan Jeruk Pontianak (Citrus nobilis var microcarpa). Skripsi. Institut Pertanian Bogor. Bogor.

Herdigenarosa, M. 2013. Pembuatan Edible Coating dari Pektin Kulit Buah Jeruk Bali (Citrus maxima) dengan Variasi Sorbitol sebagai Plasticizer. Yogyakarta: Universitas Islam Negeri Sunan Kalijaga.

Ismail, N. S. M., Ramli, N., Hani, N. M., dan Meon, Z. 2012. Extraction and Characterization of Pectin from Dragon Fruit (Hylocereus polyrhizus) using Various Extraction Conditions. Sains Malaysiana 41(1): 41-45.

Megawati dan Ulinuha, A. Y. 2014. Ekstraksi Kulit Buah Naga (Dragon fruit) dan Aplikasinya sebagai Edible Film. Jurnal Bahan Alam Terbarukan. Vol. 3 (1): 16-23.

Nainggolan, R. J. 1994, Pengaruh pH dan Lama Ekstraksi terhadap Rendemen dan Mutu Pektin dari Kulit Pisang, Lab. Teknologi Hasil Pertanian, USU, Medan.

Nazaruddin, R. N, Norziah, S. M. I., dan Zainudin, M. 2011. Pectins from Dragon Fruit (Hylocereus polyrhizus) Peel. Malays. Appl. Biol. 40 (1): 19-23.

Nugroho, A.A., Basito, R., dan Baskara, K.A. 2013. Kajian Pembuatan Edible Film Tapioka dengan Pengaruh Penambahan Pektin Beberapa Jenis Kulit Pisang Terhadap Karakteristik Fisik dan Mekanik. Teknosains Pangan Vol 2 (1): 74.

Purwanto, H., Hartati, I., dan Kurniasari, L. 2010.
Pengembangan Microwave Assisted Extractor(MAE) pada Produksi Minyak Jahe dengan Kadar Zingiberene Tinggi. Universitas Wahid Hasyim. Momentum Vol 6 (2) : 9.

Satria, Berry dan Ahda, Y. 2008. Pengolahan Limbah Kulit Pisang Menjadi Pektin dengan Metode Ekstraksi. Universitas Diponegoro, Fakultas Teknik, Jurusan Teknik Kimia: Semarang.

Sudiyono, 2012. Ekstraksi Dan Kegunaan Pektin Dari Kulit Jeruk. Universitas Widyagama Malang. Malang.

Sulihono, A., dkk. 2012. Pengaruh Waktu, Temperatur, dan Jenis Pelarut Terhadap Ekstraksi Pektin Dari Kulit Jeruk Bali (Citrus Maxima). Palembang: Jurnal Teknik Kimia No. 4, Vol. 18, Desember 2012.

Tang, P. Y., Wong, C. J., dan Woo, K. K. 2011. Optimization of Pectin From Peel of Dragon Fruit (Hylocereus polyrhizus). Asian Journal of Bilogical Sciences 4 (2): 189195.

Tarigan, M. Kaban, I. M. dan Hanum, F. 2012. Ekstraksi Pektin dari Kulit Pisang Kepok (Musa Paradisiaca). Jurnal Teknik Kimia USU, Article in Press. Universitas Sumatra Utara: Medan.

Woo, K. K., Chong, Y. Y., Li Hiong, S. K., dan Tang, P .Y. 2010. Pectin Extraction and Characterization from Red Dragon Fruit (Hylocereus polyrhizus): The Preliminary Study. Jurnal of Biological Sciences 10 (7) :631-636. 